\title{
Erratum to: Sexual Behavior and Sexual Risks Among Spanish University Students: a Descriptive Study of Gender and Sexual Orientation
}

\author{
Ángel Castro ${ }^{1} \cdot$ Pablo Santos-Iglesias $^{2}$
}

Published online: 20 February 2016

(C) Springer Science+Business Media New York 2016

Erratum to: Sex Res Soc Policy (2016) 13:84-94

DOI 10.1007/s13178-015-0210-0

The original version of this article unfortunately contained a mistake. A co-author's name was omitted from the original version of this article. The list of authors is now corrected in the authorgroup of this article.

The online version of the original article can be found at http://dx.doi.org/ 10.1007/s13178-015-0210-0.

\footnotetext{
Ángel Castro

castroa@unizar.es
}

1 Faculty of Social and Human Sciences, Department of Psychology and Sociology, University of Zaragoza, Campus Ciudad Escolar, s/n, 44003 Teruel, Spain

2 Department of Psychology, University of New Brunswick, Fredericton, Canada 